\title{
Strawberry Plasticulture in North Carolina: II. Preplant, Planting, and Postplant Considerations for Growing 'Chandler' Strawberry on Black Plastic Mulch
}

\author{
E.B. Poling
}

Additional index words. Fragaria $\times$ ananassa, fresh-dugs, plugs, fertility, frost/freeze protection, rowcovers

Summary. North Carolina is experiencing a revitalization of the strawberry industry due to the adoption of plasticulture technologies and the California cultivar Chandler, which produces excellent yields and fruit quality on black plastic mulch. With this system, berries can be harvested in just 7 to 8 months after planting. The spring harvest season can last up to 6 weeks in most years. Strawberry plasticulture growers in North Carolina typically experience yields of 17,000 to $18,000 \mathrm{lb} /$ acre $\left(19,054\right.$ to $\left.20,174 \mathrm{~kg}^{-\mathrm{ha}^{-1}}\right)$. Cash expenses for the system are about $\$ 4345 /$ acre $(\$ 10,736 / h a)$. The system requires both an overhead sprinkler system for blossom and bud frost/freeze protection, and drip irrigation for supplying water and fertilizer in the prebloom, bloom, and fruiting periods. Sandy loam and clay loam soils are ideal for forming the lo-inch-high $(25.4-\mathrm{cm})$ beds with bedding machines. Usually, $33 \%$ of the $\mathrm{N}, 50 \%$ of the $K$, and all of the $P$ is applied preplant, with the remaining $N$ and $K$ applied through the drip-irrigation system. Problems associated with the plasticulture system include higher initial investment relative to matted-row production, and only one fruiting season is possible with the anthracnose-susceptible 'Chandler' in the southeastern United States.

"Strawberry plasticulture," as it is popularly referred to in North Carolina, is technically the annual hill training system in which "green" strawberry transplants (fresh-dugs or plugs) are planted in early fall in double rows at densities of $\approx 17,400$ plants/acre $(43,000$ plants/ha $)$ on fumigated, raised beds that are covered with black plastic mulch. In this system, growers in North Carolina plan to harvest berries just 7 to 8 months after planting, compared to $\approx 12$ months for strawberries grown in matted row (MR) production. The picking season is normally 6 weeks, but, in cooler-thanaverage spring temperatures, the harvest can last 2 months. 'Chandler' is about 7 to 10 days earlier than the MR strawberry 'Earliglow', and the harvest period will extend 1 to 2 weeks past the late-midseason cultivar Cardinal. After the strawberry season ends (early to mid- June), 'Chandler' plants are destroyed and the plastic beds sometimes are re-used for summer/fall vegetable crops. 


\section{General information}

The 'Chandler strawberry. 'Chandler' (Univ. of California, Plant Patent 4487) was named in 1982 for the late William Henry Chandler, prominent author and horticulturist of the Univ. of California (Bringhurst and Voth, 1983) (Fig. 1). 'Chandler' is one of the most-important strawberry cultivars in the world; it occupies a large percentage of the southern California strawberry acreage and is a major cultivar in Louisiana, Mexico, Central America, Italy, France, and Spain. Its superior yield performance relative to other cultivars evaluated on black plastic (Poling et al., 1988) and resistance to rain and frost damage are key attributes that led to its widespread adoption by plasticulture growers in North Carolina and other states in the mid-south. 'Chandler' is popular with consumers in North Carolina because of its excellent fresh and processed quality (Fig. 1).

Many people have questioned the wisdom of North Carolina's 100\% dependency on a plasticulture strawberry cultivar that was bred for growth in California-not the humid southeastern United States. In fact, the North Carolina plasticulture industry was nearly ruined in Spring 1990, as field after field of 'Chandler' became severely infected with anthracnose fruit rot (Colletotrichum acutatum). With the loss of the emergency Section 18-C registration for Difolatan (captafol) in 1987, it became nearly impossible to grow anthracnose-free 'Chandler' nursery plants in North Carolina.

There are still no effective fungicides available for anthracnose control. and growing disease-free 'Chandler' crops basically depends upon raising the plants in very northern areas in the United States and Canada, where the summers are cool, and then fallin North Carolina.

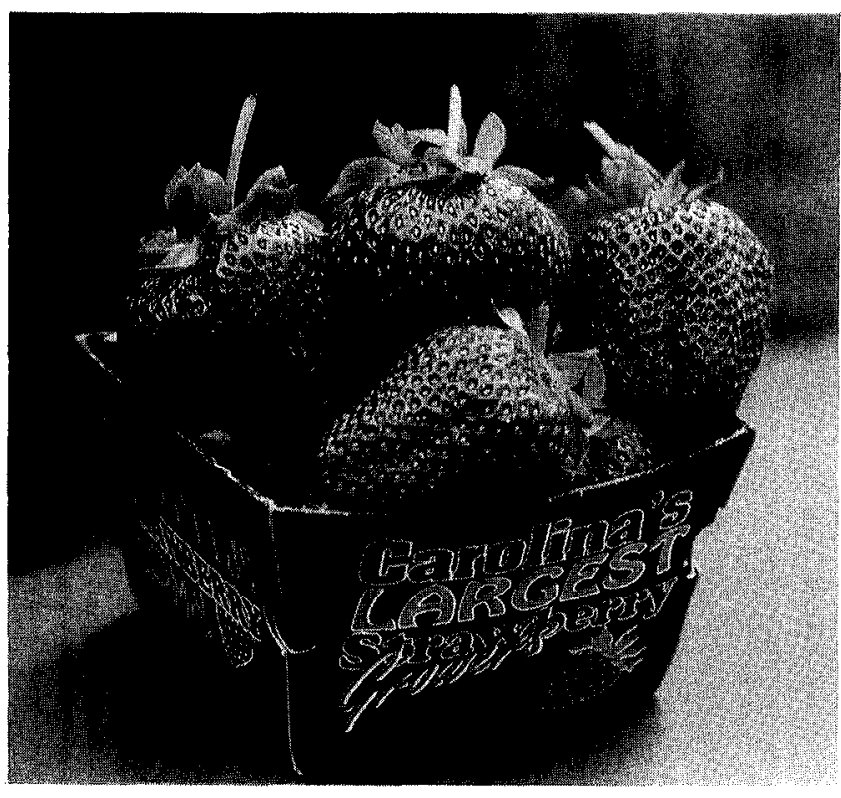

transplanting in North Carolina. After the spring strawberry season ends, 'Chandler' plants are destroyed because of this cultivar's extreme susceptibility to an$\mathrm{thr}$ a c n o s e summer infection. Furthermore, growers are encouraged to rotate planting fields and minimize overhead watering during plant establishment. Thus, growing anthracnose-susceptible 'Chandler' in North Carolina depends on sanitation and manipulation of the plant environment to avoid the disease or reduce losses.

Economics and marketing. Operating expenses for this system ofproduction are about $\$ 4345 /$ acre $(\$ 10,736 /$ ha) (Tables 1 and 2). North Carolina growers typically achieve marketable yields of 17,000 to 18,000 lb/acre $\left(19,054\right.$ to $\left.20,174 \mathrm{~kg} \cdot \mathrm{ha}^{-1}\right)$, but total yields of 'Chandler' on black plastic mulch can be less than the total yields reported for highly productive MR cultivars, such as 'Apollo' and 'Atlas' (Galletta and Scott, 1970). Pick-your-own (PYO) prices generally fall between $\$ 0.65$ and $\$ 0.75 /$ b ( $\$ 1.43$ to $\$ 1.65 / \mathrm{kg}$ ), and "ready-pick" fruit is priced $\$ 0.25$ to $\$ 0.35$ ( $\$ 0.44$ to $\$ 0.55 / \mathrm{kg}$ ) higher than PYO berries. Direct marketing (PYO, ready-pick, farmers' market) is generally more profitable for local growers of 'Chandler' than trying to sell to North Carolina supermarkets, which import large volumes of inexpensive strawberries in April and May from the southern and central coast areas of California. Atypical 'Chandler' plasticulture planting in North Carolina of 3 to 4 acres ( 1.2 to $1.6 \mathrm{ha}$ ) is not very large by comparison to those in California or Louisiana, but just a few acres can provide a good supplemental income for small and part-time growers.

Equipment needs for plasticulture. Specially equipped and trained custom applicators should be considered for fumigation. They can form beds, inject fumigant, apply plastic, and lay trickle tubes in one operation. Where custom services are unavailable for bed-shaping/fumigation/plastic-laying, the grower must purchase equipment costing about $\$ 5500$ and become certified to apply methyl bromide.

Strawberry plasticulture also requires overhead irrigation for plant establishment (fresh-dugs) and sprinkling for frost/freeze protection. The expense for solid-set irrigation can run from $\$ 1200$ to $\$ 2500 /$ acre ( $\$ 2965$ to $\$ 6177 / \mathrm{ha}$ ) depending on whether more expensive aluminum or cheaper PVC pipe is used. This does not include the expense for the diesel or electric pump, or a new pond. At least 60 to $70 \mathrm{gal} / \mathrm{min}$ (227 to 265 liters/min) of pumping capacity is necessary for each acre (0.405 ha) that is frost-protected.

More than $75 \%$ of the $\approx 700$ acres $(280$ ha) of the strawberry plasticulture industry in North Carolina uses drip irrigation. The higher lo-inch $(25-\mathrm{cm})$ beds require drip irrigation because of poor capillary water movement. The proper use of plastic mulches and drip irrigation can provide maximum control of the environment, and the most-efficient use 
of water and fertilizer. Drip irrigation systems can be designed by a specialist to irrigate any size strawberry production unit. A line-source emitter with pre-punched holes is used to maintain a continuous moist strip along the row. Because strawberries grown on plastic mulch are considered annuals and are grown for only one season, a thin disposable tubing (4 to 8 mil thick) is commonly used. Water may come from wells, ponds, lakes, municipal lines, or pits. Well water sources generally are fairly clean and require only a screen filter to remove particles. However, precipitates or other contaminants in the water should be determined by a water quality test prior to considering a drip system. Any surface water, such as streams, ponds, pits, or rivers, will contain bacteria, algae, or other aquatic life, and sand filters are an absolute necessity (Lamont, 1989).

Because the 'Chandler' berry is the mostimportant marketing tool for attracting customers to the farm, the balance of this article discusses important preplant, planting, and postplant considerations for growing this cultivar in North Carolina and, potentially, other regions as well.

\section{Replant considerations}

Site selection. The plasticulture system has been examined under a variety of site and soil conditions in North Carolina. Strawberry plasticulture is most ideally suited to the milder coastal plain (USDA hardiness zone $8 \mathrm{a}$ ) and lower Piedmont (zone 7b), but growers in the upper Piedmont and mountains of North Carolina (USDA zones $7 \mathrm{a}$ and $6 \mathrm{~b}$, respectively) are beginning to experience success with the system as well. Some of the best strawberry plasticulture sites are those with a wooded area or a windbreak on the north or northwest side of the field. This helps to reduce losses associated with wind-borne freezes in late winter and early spring. Too much wind protection and restricted-air-flow locations often lead to increased fungal pressures. Sufficient air movement is needed so that plants can dry quickly after dews and rainfall.

A north-south orientation of strawberry beds is recommended to encourage moreuniform plant development and ripening on both sides of the double-row bed. If rows are oriented east-west, plants on the north side of the bed will become partly shaded by the plants on the south side of the row during the winter season.

Soil. Soil type has a decided influence on how well the planting beds are formed. Sandy loam and clay loam soils are ideal for building and shaping the 8- to lo-inch raised beds. However, soils with a high clay content, or those that are rocky or very stony, are more
Table 1. Annual per-acre operating costs for 'Chandler' strawberry plasticulture in North Carolina with fresh-dug plants."

\begin{tabular}{|c|c|c|c|c|}
\hline Operating inputs & Units & Quantity & Price $(\$)$ & Total $(\$)$ \\
\hline Lime & ton & 1 & 26.00 & 26.00 \\
\hline Cover crop fertilization & cwt & 2 & 10.30 & 20.60 \\
\hline Cover crop planting & $\mathrm{lb}$ & 50 & 0.69 & 34.50 \\
\hline Prcplant fertilizcr & $\mathrm{lb}$ & 500 & 0.08 & 40.00 \\
\hline Bed and band fertilizer & $\mathrm{lb}$ & 300 & 0.50 & 150.00 \\
\hline Custom fumigate/plastic & acre & 1 & 680.00 & 680.00 \\
\hline Drip tape & acre & 3.33 & 87.00 & 290.00 \\
\hline Plants (fresh-dugs) & each & 17,424 & 0.075 & 1306.80 \\
\hline Custom plant & each & 17,424 & 0.012 & 209.09 \\
\hline Pest control & acre & 7 & 12.89 & 90.23 \\
\hline Weed control & acre & 4 & 5.58 & 22.32 \\
\hline Advertising & acre & 1 & 100.00 & 100.00 \\
\hline Fuel, lube, repairs & acre & 1 & 126.51 & 126.51 \\
\hline \multicolumn{5}{|l|}{ Labor } \\
\hline Preplant & h & 7.52 & 4.80 & 36.10 \\
\hline Plant and production & $\mathrm{h}$ & 3.18 & 4.80 & 15.26 \\
\hline Supervision & $\mathrm{h}$ & 125 & 5.25 & 656.25 \\
\hline Irrigation & $\mathrm{h}$ & 22.44 & 4.80 & 107.71 \\
\hline Postharvest & $\mathrm{h}$ & 8 & 4.80 & 38.40 \\
\hline Operating interest & $\$$ & $3,949.89$ & 0.10 & $\underline{395.00}$ \\
\hline Total operating costs ${ }^{y}$ & & & & 4344.89 \\
\hline
\end{tabular}

${ }^{z}$ Prepared by K. Baldwin and S. Mickey, Chatham County Agr. Extension Agents, North Carolina Agr. Ext. Serv.

YOther costs to be paid: Liability, insurance, income/FICA taxes on employees, machinery investment, equipment investment, irrigation investment, and pond construction.

Table 2. Annual per-hectare operating costs for 'Chandler'strawberry plasticulture in North Carolina with fresh-dug plants.

\begin{tabular}{lccrr}
\hline Operating inputs & Unit & Quantity & Price (\$) & Total (\$) \\
\hline Lime & $\mathrm{t}$ & 2.24 & 28.68 & 64.25 \\
Cover crop fertilization & $\mathrm{kg}$ & 224.17 & 0.23 & 50.90 \\
Cover crop planting & $\mathrm{kg}$ & 56.00 & 1.52 & 85.25 \\
Preplant fertilizer & $\mathrm{kg}$ & 560.42 & 0.18 & 98.84 \\
Bed and band fertilizer & $\mathrm{kg}$ & $\mathbf{3 3 6 . 2 5}$ & 1.10 & 370.64 \\
Custom fumigate/plastic & $\mathrm{ha}$ & 1 & 1680.26 & 1680.26 \\
Drip tape & $\mathrm{ha}$ & 8.23 & 87 & 716.58 \\
Plants (fresh-dugs) & $\mathrm{each}$ & 43,054 & 0.075 & 3229.06 \\
Custom plant & $\mathrm{each}$ & 43,054 & 0.012 & 516.65 \\
Pest control & $\mathrm{ha}$ & 17.30 & 12.89 & 222.96 \\
Weed control & $\mathrm{ha}$ & 9.88 & 5.58 & 55.15 \\
Advertising & $\mathrm{ha}$ & 1 & 247.10 & 247.10 \\
Fucl, lube, repairs & $\mathrm{ha}$ & 1 & 312.60 & 312.60 \\
Labor & & & & \\
Preplant & $\mathrm{h}$ & 18.58 & 4.80 & 89.20 \\
Plant and production & $\mathrm{h}$ & 7.86 & 4.80 & 37.71 \\
Supervision & $\mathrm{h}$ & 308.87 & 5.25 & 1621.57 \\
Irrigation & $\mathrm{h}$ & 55.45 & 4.80 & 266.15 \\
Postharvest & $\mathrm{h}$ & 19.77 & 4.80 & 94.89 \\
Operating interest & $\$$ & $9,760.04$ & 0.10 & 976.03 \\
Total operating costs & & & & $\mathbf{1 0}, 736.08$ \\
\hline
\end{tabular}

${ }_{\text {zrepared by K. Baldwin and S. Mickey, Chatham County Agr. Extension Agents, North }}$ Carolina Agr. Ext. Serv.

yOther costs to be paid: Liability insurance, income/FICA taxes on employees, machiwery investment, equipment investment, irrigation investment, and pond construction.

difficult to prepare. As a general rule, the physical conditions of the soil in relation to its bed-making characteristics and internal drainage are more-important considerations than 
Fig. 2. Freshly "pressed" strawberry bed before fumigation and plastic mulch application. Prior to bedpressing and fumigation, this Norfolk sandy loam soil was well-worked, free from plant debris, and bad adequate moisture for weed seed termination. The top of the bed is smooth (no pockets) and the bed shoulders are well-formed. soil fertility. High clay content, stones or rocks, and underlying hardpan are moredifficult conditions to manage than low $\mathrm{pH}$ or a lack of minerals, which can be balanced through the applications of lime and appropriate fertilizers

Growers are encouraged to rotate strawberry field sites as often as possible, but the general practice in North Carolina is to crop strawberries continuously on the same land because of existing irrigation lines and market location considerations. The elimination of methyl bromide soil preplant fumigant will likely change this practice, and growers may be forced to evaluate the benefits of field rotation, especially with regard to controlling soil-borne strawberry diseases, nematodes, and insect pests that can build up in continuously cropped (untreated) fields.

Water drainage. The raised beds enhance internal soil water drainage, but plasticulture growers frequently encounter problems with getting rid of excess "surface water." This problem occurs because $50 \%$ of a strawberry field has been covered with an impermeable plastic film. For this reason, it is desirable to have a field with enough slope so that surface water is removed uniformly and gently from the field after periods of heavy precipitation, without causing erosion or leaving puddles. On fields with more than $2 \%$ slope, continuous overhead sprinkling for fresh-dug plant establishment may cause severe soil erosion. Unlike highly perishable fresh-dug transplants, plug plants do not require intense overhead sprinkling for postplant care and survival (see the section on planting).

Soil preolant fertility. A soil test is made several months in advance of planting to provide an indication of how much dolomitic lime is needed to raise the soil $\mathrm{pH}$ to

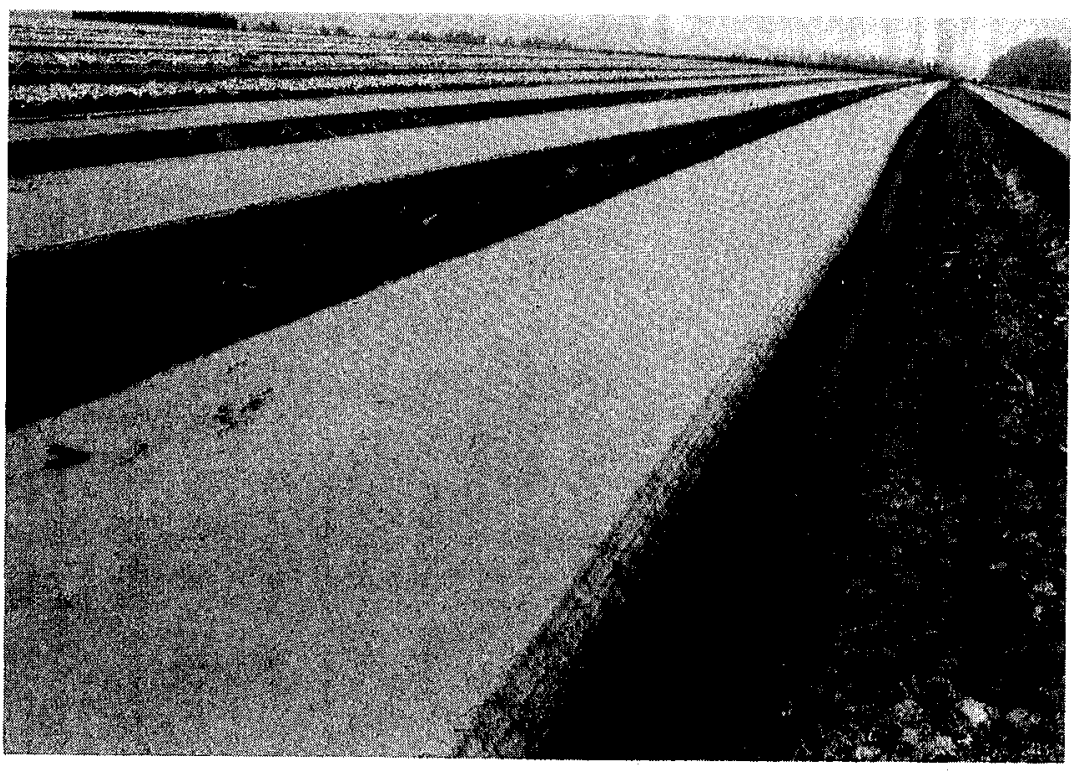

6.0. About $33 \%$ of the N, $50 \%$ of the $\mathrm{K}$, and all of the recommended $\mathrm{P}$ (based on soil testing) is applied preplant, with the remaining $\mathrm{N}$ and $\mathrm{K}$ being applied in a 1:1 ratio through the drip irrigation system. For sandy soils that do not retain $\mathrm{K}$ or $\mathrm{N}$ well, the usual recommendation for a preplant fertilizer program is to broadcast $120 \mathrm{lb} \mathrm{K} / \mathrm{acre}(135 \mathrm{~kg}$. $\left.\mathrm{h} \mathrm{a}^{-1}\right)$, in addition to the $60 \mathrm{lb}$ N/acre (67 $\left.\mathrm{kg} \cdot \mathrm{ha}^{-1}\right)$. The recommended fertilizer source for Kis potassium sulfate. Ammonium nitrate is the usual preplant $\mathrm{N}$ fertilizer, and it is either broadcast or banded 4 inches $(10 \mathrm{~cm})$ deep in the bed center. Essentially, these preplant fertilizer applications of $\mathrm{N}$ and $\mathrm{K}$ supply early nutrition to 'Chandler' in fall and early winter, when North Carolina growers typically do not run their drip irrigation systems. Soil tests for boron are generally not very accurate and, as a rule, growers make a preplant soil surface spray of $\approx 1 \mathrm{lb} \mathrm{B} /$ acre using solubor $(20 \%$ B) in 100 gal of water/acre.

Fumigation. Methyl bromide/chloropicrin fumigation has been a standard practice in California and Florida, where annual hill plastic mulch culture has been practiced since the 1960s. Beds are fumigated with methyl bromide for weed, nematode, disease, and insect control. Annual hill production on the same site year after year is not advisable without pre-plant fumigation. The amount of material actually applied per acre will depend on row width and will be a percentage of the broadcast rate. The air temperature should be at least 50F (10C). The soil should be well-worked, free from plant debris, and have adequate moisture (for weed seed germination) (Figs. 24). To have good soil moisture for forming the beds, it is frequently necessary to wet up the sprinkler irrigation system and apply $\approx 0.5$ inch $(1.3 \mathrm{~cm})$ of water 1 to 2 days in advance of bed-making and fumigation. If both weather and soil are warm, most fumigants escape from the bed in about 7 days. An additional precaution to reduce the likelihood of methyl bromide injury to the strawberry transplant would be to cut or punch plant holes through the plastic mulch a day or two prior to planting (Pig. 5 top).

Strawberry bed. Most growers in southeastern North Carolina have 10-inch $(25-\mathrm{cm})$-high "super-beds" to promote the development of larger root systems and more branched crowns. The super-beds provide a nearly ideal air-soil-water environment for vigorous strawberry root development. The beneficial effect of these beds on root growth is observed easily by excavating the soil beneath the plastic mulch film at the end of the season (see Fig. 12). A few roots may be found as deep as 24 inches $(0.61 \mathrm{~m})$, but the largest concentration is in the upper 10 to 12 
inches $(25$ to $30 \mathrm{~cm}$ ) of soil. Grower yields of 'Chandler' on fertile sandy loam soils with lo-inch $(25-\mathrm{cm})$-high beds have exceeded $36,000 \mathrm{lb} /$ acre per year $\left(40 \mathrm{t} \cdot \mathrm{ha}^{-1}\right)$ for 3 years in a row on several sites in southeastern North Carolina.

The lo-inch $(25-\mathrm{cm})$-high plastic mulch beds are typically 32 inches $(0.81 \mathrm{~m})$ wide at the base and 30 inches $(0.76 \mathrm{~m})$ wide on the top. The beds are slightly crowned so that water will run off and not rest on the plastic [a bed with a 30-inch $(0.76-\mathrm{m})$ top should slope from the center to the edge with a drop of 1.25 inches $(3.2 \mathrm{~cm})]$. With lower bed height, the long fruit trusses of 'Chandler' come in direct contact with the soil in the row aisles. Thus, it becomes necessary to apply straw mulch to the aisles to keep the berries clean-this is not necessary with 10-inch (25 $\mathrm{cm})$-high beds. Bed centers are 4.5 to $5 \mathrm{ft}$ (1.37 to $1.52 \mathrm{~m})$.

Drip tubing installation. Drip tubing is installed with the orifices facing upwards. The tubing is typically buried 1 to 2 inches deep in the bed center. During installation, several workers should be watching to ensure that the tubing maintains its orificeupwards orientation, to assist in case tubing becomes tangled in the injector, and to signal when the drip tape reel is empty. Tubing ends should be closed off by kinking-or knotting, until the tubes are hooked up to the system. Generally, growers do not use the drip system until late winter/early spring; fall irrigation is applied by overhead sprinklers.

Cover crops on sloping terrain. A s soon as the land is fumigated and mulched, it is often a good idea to broadcast $\approx 50 \mathrm{lb}$ of annual ryegrass/acre $\left(56 \mathrm{~kg} \cdot \mathrm{ha}^{-1}\right)$ over the entire field. The ryegrass can be spread the same day fumigation is completed. The ryegrass will reduce soil washing in the aisles after heavy rains or irrigation for plant establishment (fresh-dugs) on sloping terrain. It is vital to dress the land immediately after fumigating so that surface water can flow easily out of the rows. It is much more difficult to deal with surface drainage problems after the ryegrass is established. Obviously, it is best not to apply any pre-emergent herbicide to the aisles if a "living mulch" is grown for the fall and winter season. In fact, very few herbicides are labeled for strawberry plasticulture, and growers should check with the Cooperative Extension Service or their crop consultant if there are questions about available herbicides, rates, and timing of application.

\section{Planting considerations}

Plant quality. The success of a strawberry plasticulture planting, in large part, depends on the health and vigor of the planting stock. Plants should be purchased from a

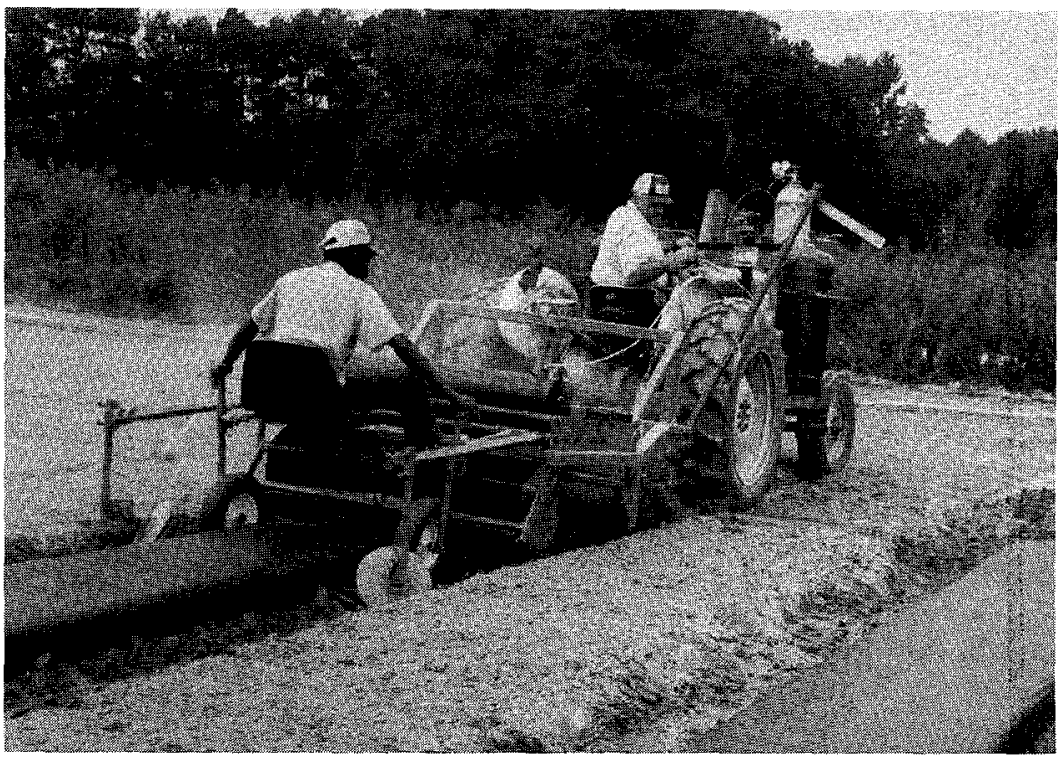

reputable nursery. 'Chandler' plants should be true-to-variety, and not a tissue-culture mutation of the cultivar. The plants should be free of insects, diseases, nematodes, and viruses. The North Carolina Strawberry Assn., Inc. (Association Management, Box 52276, Raleigh, NC 27612) maintains a current listing of 'Chandler' nursery plant sources in the United States and Canada for interested growers.

Plant type. Plug plants are generally more expensive to purchase than fresh-dug strawberry plants, but they do have the advantage of being suitable for mechanical transplanting with a water-wheel or pot mulch planter, whereas fresh-dug plants most often are transplanted by hand. The establishment procedure for highly perishable fresh-dug transplants depends on intense overhead sprinkling for 1 to 2 weeks, depending on weather. Commercial grower experiences in North

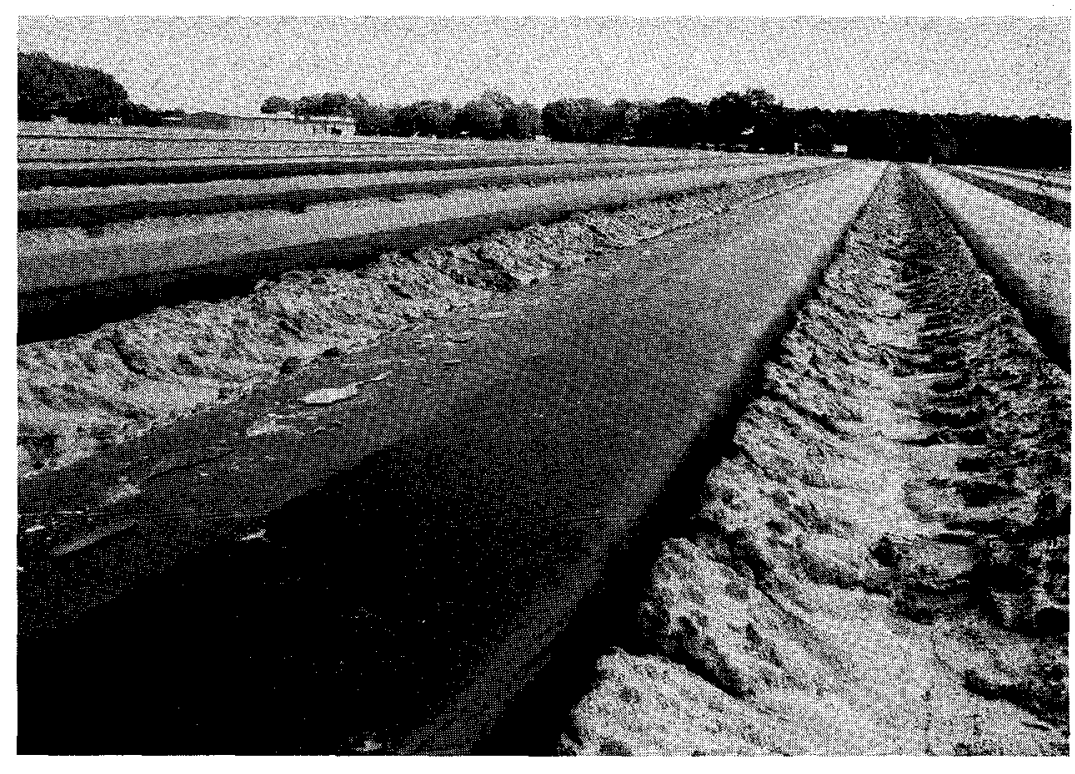

Fig. 3. This basic unit is designed for forming the bed and applying the fumigant and plastic mulch in one field pass. The unit can be modified easily for applying drip tape as well.

Fig. 4. The black plastic film must be in direct contact with the soil beneath to achieve the desired soilwarming effect needed for good plant establishment, growth, and fruiting daring North Carolina's "cool" seasons (fall, winter, and early spring). 

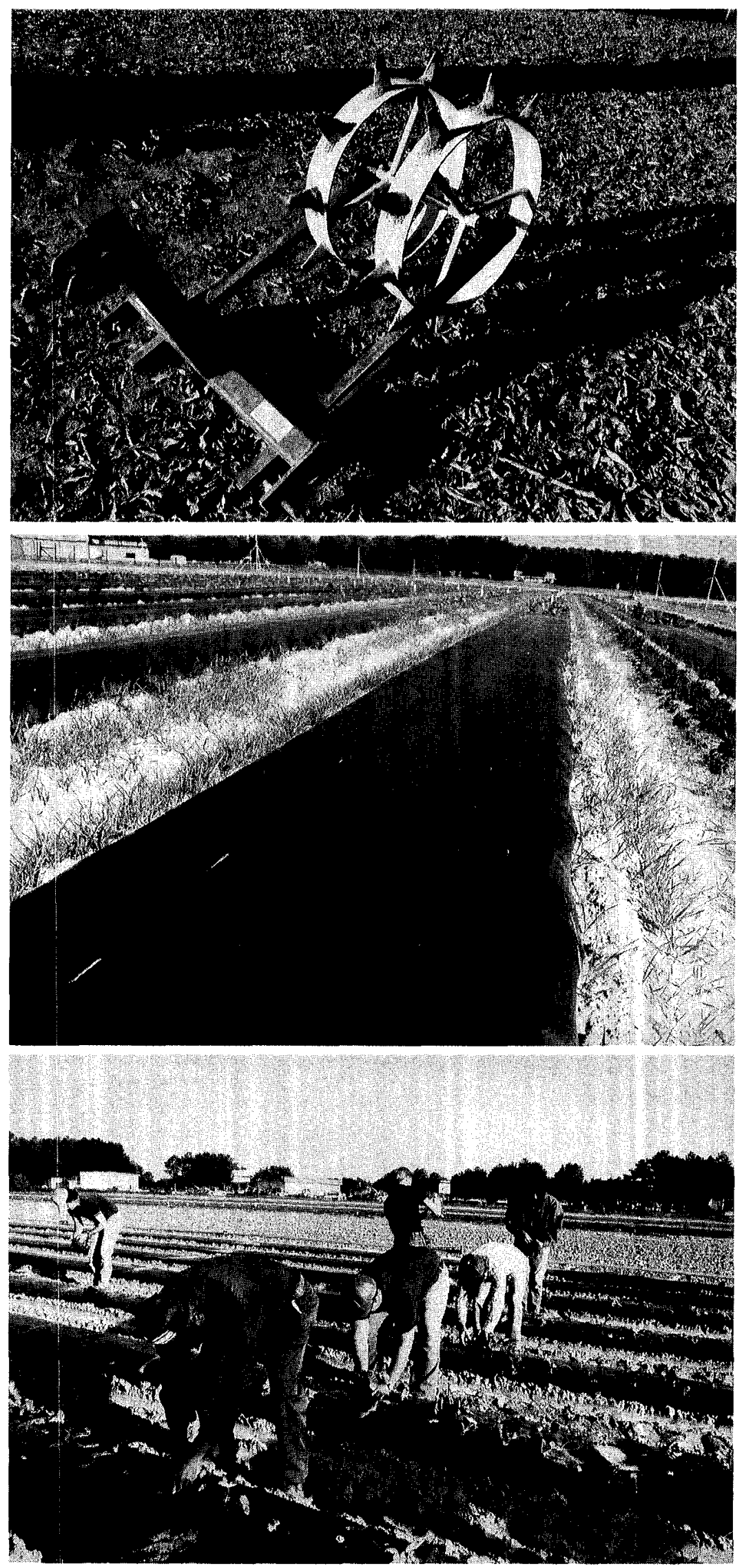

Fig. 5. (Top) Specially constructed spacing wheel that also opens a narrow bole for planting. (Middle) The plants will be spaced $\approx 12 \times 12$ inches $(30 \times 30 \mathrm{~cm})$ and be offset for improved light and air circulation between rows. (Bottom) Planting of fresh-dug strawberries is done by band.
Carolina with plug plants indicate that these do not require intensive overhead sprinkling for post-planting care. Plugs are definitely recommended over fresh-dugs for part-time growers who do not have the time to oversee the continuous overhead watering of freshdug plants during the first week following field transplanting. Also, less-experienced growers are encouraged to consider planting plugs because they are more "mistake-proof than highly perishable fresh-dug plants. Transplanting dates for plugs can also be slightly later than for fresh-dugs without as great a yield reduction. This is because plugs establish more quickly than fresh-dugs after transplanting. Plug plants have been found to be comparable to fresh-dug plants in both marketable yield and fruit size (Poling, 1992).

Planting period. Until recently, plasticulture growers could not obtain fresh-dug (green) plants until sometime in very late September or early October from northern U.S. and Canadian nurseries. This happens to be the best time of year for transplanting in the lower piedmont and southeastern North Carolina, but earlier transplanting dates are needed to achieve full crops in colder climatic areas, such as the upper piedmont and mountains of North Carolina (USDA zones 7a and $6 \mathrm{~b}$, respectively), Virginia, Delaware, Maryland, and New Jersey. Growers in western North Carolina can achieve target planting dates in mid-September by using fresh "container-grown" strawberry plug plants.

Plant spacing. There are two plant rows per bed ("double row hill"). Plants between rows are generally offset for improved light and air circulation (Fig. 5 middle). There is usually 12 to 14 inches ( 30 to $36 \mathrm{~cm}$ ) between the plant rows, and 12 to 16 inches (30 to $41 \mathrm{~cm}$ ) between plants in the row. With $5 \mathrm{ft}(1.52 \mathrm{~m})$ between bed centers, 17,400 plants/acre $(43,000$ plants/ha $)$ will be required at the $12 \times 12$-inch $(30.5 \times 30.5$ $\mathrm{cm})$ spacing; 14,900 plants/acre $(36,800$ plants/ha) at the $14 \times 12$-inch $(35.6 \times 30.5$ $\mathrm{cm})$ spacing; and 13,000 plants/acre $(32,120$ plants/ha) at the $16 \times 12$-inch $(40.6 \times 30.5-$ $\mathrm{cm})$ spacing.

\section{Storage, handling, and transplanting procedures}

Fresh-dugs. Freshly dug plants may be stored in a cold room at $40 \mathrm{~F}$ (4.4C) for 1 to 2 days before setting. Storage for a longer period can make the plants more difficult to establish. Plants in a nursery box or crate are packed tightly enough (typically packed 500 to 1000 plants per crate) to make them prone to what is called a "heat" "-rendering them unfit for subsequent planting in the grower's field. It is very important to cool the plants prior 
to transit. During hot weather, it may be necessary to run water through the crates to keep plants cool.

The fresh-dug strawberry plant is handtransplanted through the plastic mulch in 2.5 -inch $(6.4-\mathrm{cm})$ slits cut by specially constructed spacing wheels that also open a narrow hole for planting (Fig. 5 bottom). This equipment can reduce substantially the time required to set fresh-dug strawberries $(\approx 40$ $\mathrm{h} / \mathrm{acre}$, or $\approx 100 \mathrm{~h} / \mathrm{ha}$ ). Some root pruning may be needed to shorten roots to 5 to 6 inches (12.7 to $15.2 \mathrm{~cm})$ prior to transplanting. The plants need to be set so that the midpoint of the crown is level with the soil surface. If plants are set too deep, the plants are unthrifty and crowns may rot and plants may die. If planted too shallow, the root system is exposed, which can result in poor rooting and shifting of the plants. Often plants may be set at the right depth, but either be in a small depression or have soil ridged around the crown. When irrigation is initiated to establish plants, the depression can fill and bury the crown, or the ridge may erode and expose the roots. A firm plant bed assists in preventing the bed from settling or eroding.

Overhead irrigation should begin as soon as plants are set-no more than $1 \mathrm{~h}$ should elapse. These plants will require irrigation varying from 5 to 7 days after transplanting. Each morning, irrigation should be started when plants show moderate wilt, and should continue until the hot part of the day has passed. After a few days, irrigation can be initiated a little later in the morning, and can be discontinued earlier in the afternoon. The primary purpose of these irrigations is to prevent foliage loss until the root system can develop and absorb sufficient moisture to sustain the plant. Plants should have three or more filly green leaves remaining at the end of the establishment period (Fig. 6). Only a relatively small volume of water is required for mist cooling-we have been successful using $1 / 10$ inch $(0.25 \mathrm{~cm}) / \mathrm{h}$. Figure 7 shows the appearance of 'Chandler' fresh-dug plants in late December.

Plugs. Extended storage of the plantlets or tips generally is not needed. Northern commercial nurseries can harvest fresh tips weekly from early July through mid-October. The tips are shipped by refrigerated truck to the grower's farm for delivery $\approx 35$ days prior to field-transplanting. Tips can be stored up to 2 weeks at 34 to $40 \mathrm{~F}$ ( 1.1 to $4.4 \mathrm{C}$ ) without deterioration in quality. The boxes (containing $\approx 1000$ plantlets) must be stacked loosely so that the cool air can circulate freely around the boxes. The strawberry tips are living, respiring plants and must be kept cool until the grower is ready to root them under mist. The relative humidity in the cooler

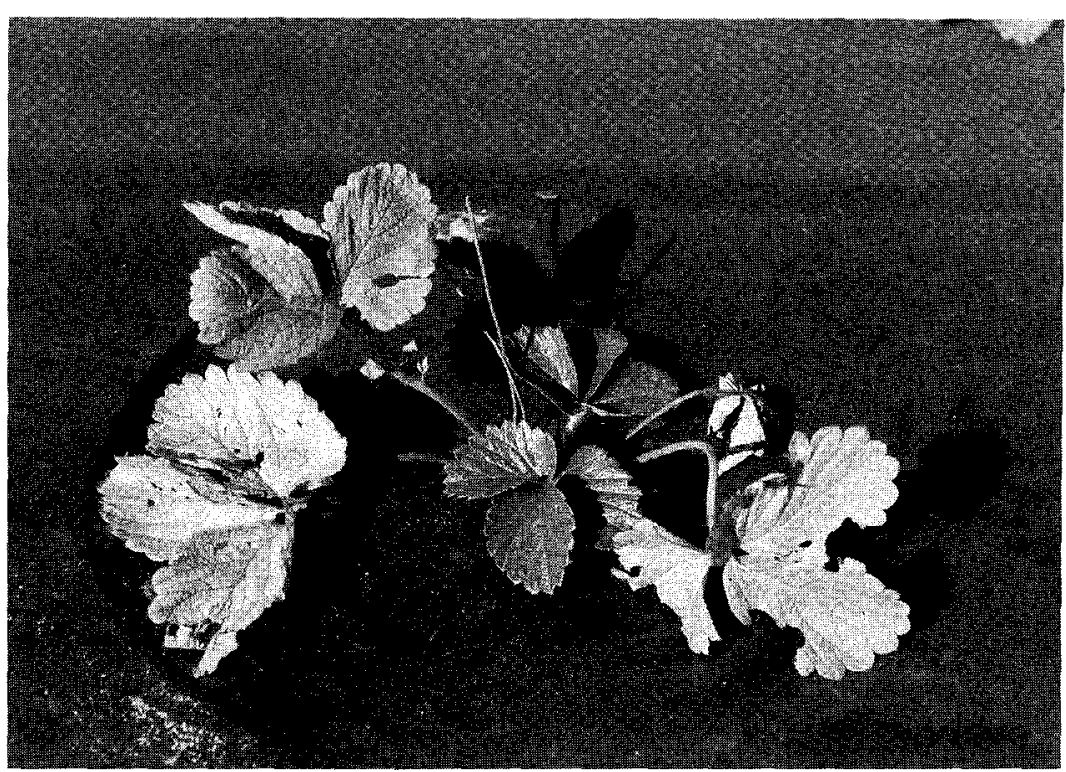

should be maintained around $75 \%$ to $80 \%$.

Prior to rooting, additional plantlet preparation is needed to trim away excess runnercords. An approximate $3 / 8$ - to $1 / 2$-inch (1.0- to $1.3 \mathrm{~cm})$ runner "stub" serves to anchor the plantlet until new roots develop (Fig. 8). Fresh strawberry tips are best rooted under a fine mist, which will wet the foliage yet put very little excess water on the soil. The goal is to keep moisture on the leaves until the plant is well-rooted-about 7 to 10 days. As the roots form, the plants can be weaned from the mist and allowed to get their moisture from the soil. This is a gradual reduction over 2 to 5 days. Two weeks after sticking, most plants should be able to be pulled from the cell with the root ball remaining intact (Fig. 9). When that occurs, misting can be terminated.

Strawberry plants raised in containers are grown in specially prepared growing media. Many different media are available, but a
Fig. 6. Fresh-dug transplants should have three or more healthy original leaves remaining at the end of the establishment period. Note the development of two new leaves from the crown $\approx 3$ weeks after transplanting.

Fig. 7. The appearance of fresh-dug 'Chandler' plants in late December (plants transplanted in the 3rd week of September). Actually, these plants may be considered "too advanced," as the leaves from plants in the row should not touch until late winter.

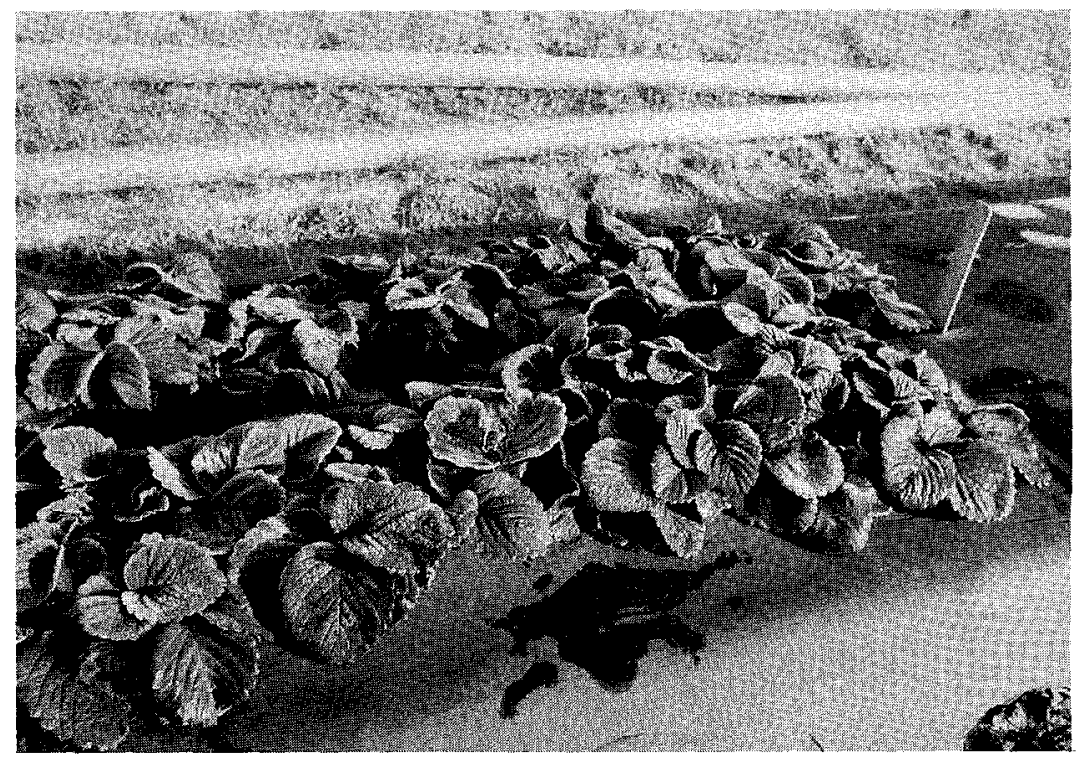




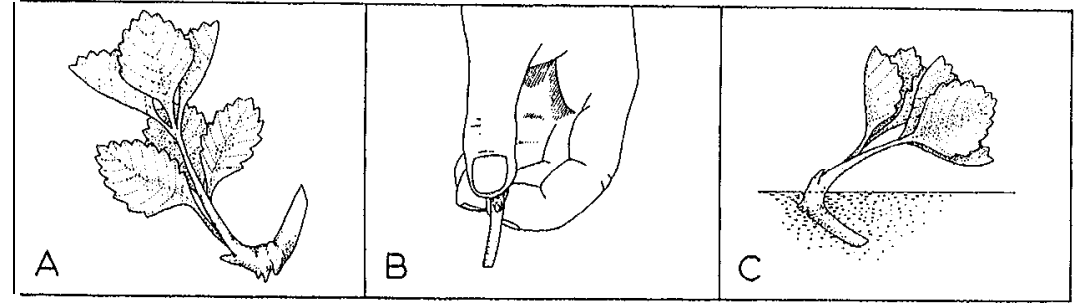

Fig. 8. (A) Fresh plantlet used for rooting has one to two epanded leaves with the first root nodules visible. (B) Three-eighths- to 0.5-inch ( 1 to 1.3-cm) of the runner attached so that it can be inserted in the media to bold the plantlet secure. (C) Sideview of the plantlet inserted in a 2-3/8-inch (6-cm) plug.

Fig. 9. Two weeks after sticking, most plan\& should be able to be pulled from the cell with the root ball remaining intact.

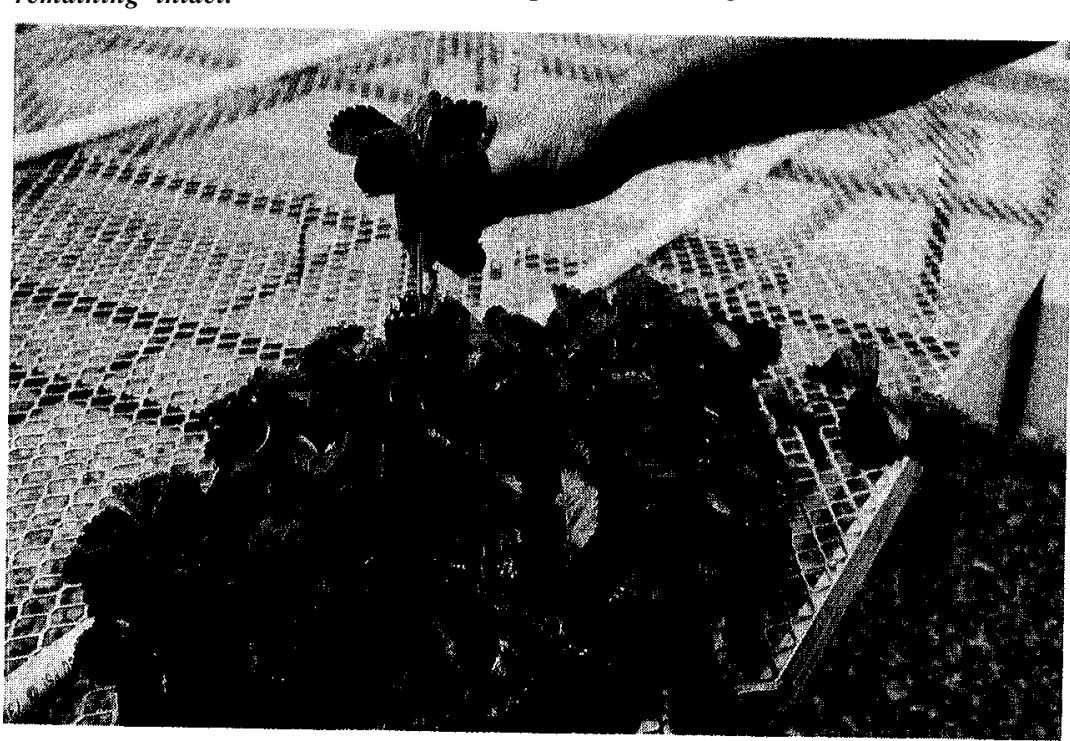
$\left(0.11 \mathrm{~m}^{3}\right)$ of media for $\approx 1000$ tips in 60 -cell be used to transplant strawberry plugs mechanically. Careful size-grading of tip plants will produce more-uniform plugs for efficient machine transplanting. A few hours of overhead sprinkler irrigation after transplanting plugs is also recommended.

\section{Postplant care}

Postplant fertility. In southeastern soilless media based on peat, sand, grit, vermiculite, perlite, polystyrene, or other materials is recommended. This requires $\approx 4 \mathrm{ft}^{3}$ rigid plastic trays measuring $2-3 / 8 \times 12 \times 20$ inches $(6 \times 30.5 \times 50.8 \mathrm{~cm})$. The 60 -cell tray is suggested for small and medium-size strawberry tips. If the tips are quite variable in plantlet length, it is well worth the extra step to grade the tips into large-, medium-, and small lots. The large tips should be rooted in 50-cell trays, the medium tips in 60-cell trays, and the smaller tips rooted in 72-cell trays. Sticking large tips [>5 inches $(12.7 \mathrm{~cm})]$ in the same tray with small tips [2 to 3 inches $(5.1$ to $7.6 \mathrm{~cm})$ ] will result in light competition and irregular root growth of the smaller, shaded tip plants. During misting, shaded tips are susceptible to botrytis infection.

After the misting cycle is complete, trays are moved to a fully exposed gravel pad for another 2 to 3 weeks of growth and acclimation before field transplanting. During this final field-conditioning phase, a single daily watering is suggested, along with a weekly supplemental drench of a complete fertilizer material. A root-bound plug is desirable for mechanical transplanting; plugs for transplanting by hand can be set before this stage is reached. In transplanting plugs, the plant crown (bud) should be just above the soil line, and not buried.

Plug plants pose less-serious problems than fresh-dugs for field transplanting. Pot mulch planters or vegetable water wheels can

North Carolina, drip irrigation applications begin at first bloom (late February) and continue through harvest (ending in late May or early June). In conjunction with a plant analysis program, drip fertigation has the potential to improve $\mathrm{N}$ and $\mathrm{K}$ efficiency and, possibly, berry firmness and quality. Over about a 100day period from late February through late May or early June, $\mathrm{N}$ and $\mathrm{K}$ maintenance drip applications are made daily, or weekly, at the equivalent of $1 \mathrm{lb} / \mathrm{acre}$ per day $\left(1.12 \mathrm{~kg} \cdot \mathrm{ha}^{-1}\right)$ of $\mathrm{N}$, along with $1 \mathrm{lb} / \mathrm{acre}$ per day $(1.12 \mathrm{~kg}$. $\mathrm{h} \mathrm{a}^{-1}$ ) of $\mathrm{K}_{2} \mathrm{O}$. We have not been able to observe yield or fruit quality benefits in 'Chandler' by injecting higher amounts of $\mathrm{K}_{2} \mathrm{O}$ relative to $\mathrm{N}$ in this maintenance program. (unpublished data).

Biweekly plant analysis is used in the late winter and early spring to make more-precise determinations ofnutrients that may become limiting for optimum plant growth and fruit production. Most recent, fully expanded leaves are selected and analyzed for identification of nutritional problems. The following sufficiency ranges are used for "Chandler" strawberry in North Carolina: N, $3.0 \%$ to $4.0 \%$; P, $0.2 \%$ to $0.4 \%$; $\mathrm{K}, 1.1 \%$ to $2.5 \%$; $\mathrm{Ca}, 0.5 \%$ to $1.5 \% ; \mathrm{Mg} 0.25 \%$ to $0.45 \% ; \mathrm{Fe}, 50$ to 150 ppm; $\mathrm{Mn}, 30$ to $100 \mathrm{ppm}$; Zn, 15 to $50 \mathrm{ppm}$; $\mathrm{Cu}, 4$ to $15 \mathrm{ppm}$; and $\mathrm{B}, 25$ to $50 \mathrm{ppm}$. Petioles are detached and analyzed for nitrate nitrogen concentration. Experience to date indicates that highest yields are obtainedwhen petiole nitrate nitrogen ranges from 5500 to $6000 \mathrm{ppm}$ early in the season, to 800 to 1200 $\mathrm{ppm}$ at the end of the season (R. Campbell, personal communication).

Water management and operation. As the strawberry plant grows, larger quantities of water are needed because root systems become more extensive and more foliage is present. In the fall, other than for plant establishment in the first 2 weeks after planting, relatively little water is needed. In the late winter, as the drip fertigation program begins (late February/early March), water is furnished to the plants through drip fertigation, As foliage and blossoms begin to develop rapidly in March and early April, more water is needed. Peak water use occurs in May, during harvest; obviously, more water is needed under hot, dry conditions to replace evaporative loss.

Measuring water loss. (Adapted from 
Lamont, 1991.) Water loss by evaporation can be measured by an open pan and is usually quoted by agricultural weather reports as pan evaporation. Afar easier method of determining daily water need for crops on drip irrigation system is the use of tensiometers. A tensiometer consists of a porous, porcelaintipped tube containing water with a vacuum gauge at the top. The tensiometer is placed at root-zone depth with the porous tip buried in the soil. As water attempts to move from the porous tip, a vacuum reading (in centibars of soil suction) indicates the moisture status of soils. Tensiometers work well for the sandy soils commonly found in many vegetable and strawberry growing areas in North Carolina. A value of 0 means the soil is completely saturated with water. A reading of 10 represents a normal field capacity soil water status. The system should be turned on when a reading of 20 to 30 appears on the gauge.

Tensiometers usually are installed in pairs, called a "station," one at a 6 -inch (15.2-cm) depth and one at a 12 -inch $(30.5-\mathrm{cm})$ depth. The system is turned on when the 12-inch $(30.5-\mathrm{cm})$ tensiometer reads 20 to 30 , and is turned off when the shallow [6-inch (15.2$\mathrm{cm})$ ] tensiometer drops to 10 or below. Tensiometers can be purchased with solenoid switches to completely automate the processes.

Rowcovers. It should be realized that rowcovers should not be regarded as frost protection systems. For total frost protection, bonafide sprinkler irrigation systems are the answer. Rowcovers do provide temperature modification, and crops may be slightly early if covers are applied in winter, but the practical value of having a winter rowcover would depend on obtaining a very substantial price for the early crop (Poling et al., 1991). Overwintering covers (strips or floating) may be justified in western North Carolina and more northern climates.

We have observed that floating covers do provide economic benefits in late winter and early spring during advective or windborne freezes (Fig. 10). During such freezes, sprinkler irrigation cannot be used to protect the crop because of high winds. The floating covers can be deployed for short durations. The covers can be returned to storage once field conditions have moderated. This will help to extend the life of the covers- 2 or 3 years is typical.

Spring frost/freeze control. Overhead sprinkler irrigation is still the best and mostreliable means for protecting strawberry blossoms from cold injury in March and April. In North Carolina, it is not uncommon to pump 10 or more nights each spring for as many as 8 to $10 \mathrm{~h}$ each night. If, for example, the pump is used four consecutive nights, for an

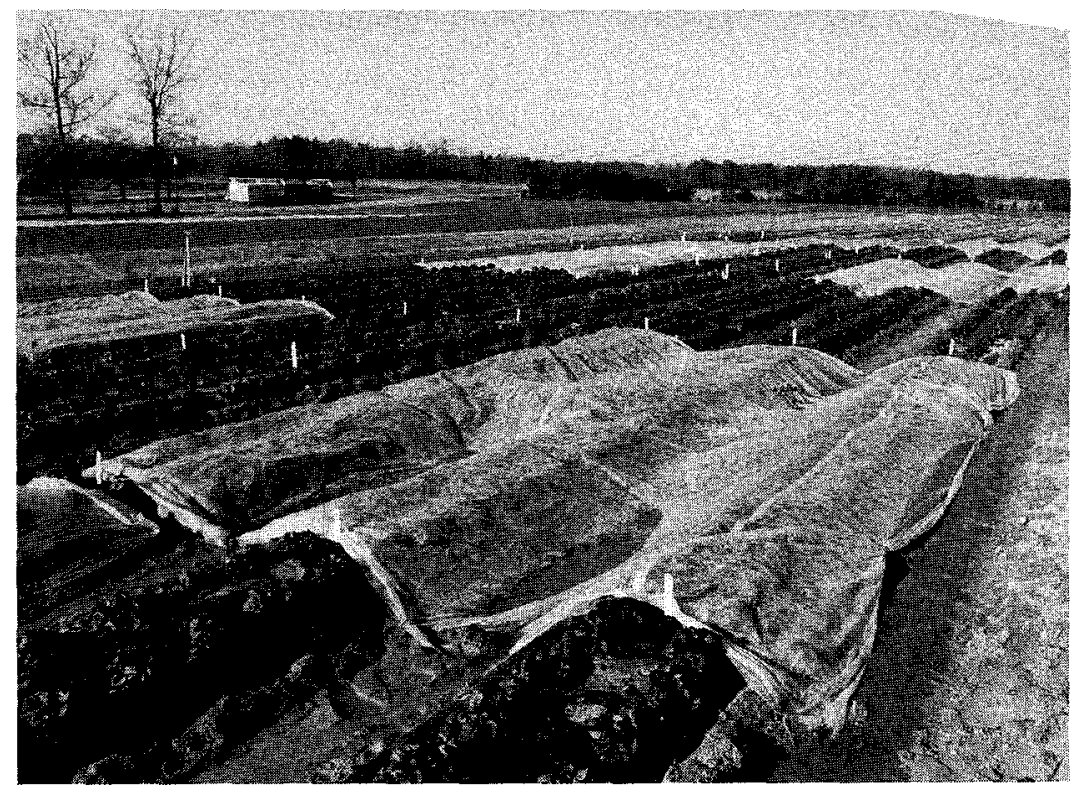

average of $10 \mathrm{~h}$ each night at the rate of $1 / 8$ inch $/ \mathrm{h}(0.32 \mathrm{~cm} / \mathrm{h}), \approx 136,000 \mathrm{gal} \quad(514,800$ liters) of water will be needed for protecting just 1 acre (0.405 ha). The irrigation water provides heat to the plant as the temperature of the water drops to $32 \mathrm{~F}(0 \mathrm{C})$, and especially as it freezes. As long as the temperature of the flower or fruit stays above $30 \mathrm{~F}$, no damage usually results. The lower the air temperature the greater the amount of water needed to maintain the temperature of the flowers and fruit above the damaging level. Open strawberry flowers are more prone to freeze damage than green fruit, which, in turn, are more sensitive than ripe fruit. If wind speed is 10 to $15 \mathrm{mph}$ (16 to $\left.24 \mathrm{~km} \cdot \mathrm{h}^{-1}\right)$ or greater, water application with this technique is erratic, and plants as well as flowers and fruit can be damaged severely. With little or no wind, $\approx 0.15 \mathrm{inch} / \mathrm{h}\left(0.38 \mathrm{~cm} \cdot \mathrm{h}^{-1}\right)$ of irrigation is required for frost protection down to a temperature of $22 \mathrm{~F}(-5.6 \mathrm{C})$, and $\approx 0.25 \mathrm{inch} / \mathrm{h}$ $\left(0.64 \mathrm{~cm} \cdot \mathrm{h}^{-1}\right)$ from 22 to $18 \mathrm{~F}(-5.6$ to $-7.8 \mathrm{C})$. Sprinklers should be turned on at $34 \mathrm{~F}$ (1.1C), and left on until the ice begins to melt and continues to melt when no additional irrigation is applied. Thermometers should be calibrated in an ice bath and placed in the lowest $\operatorname{spot}(\mathrm{s})$ in the field, fully exposed to the sky, and just above the mulch (not protected by nearby plants).

Plant size management. These final comments are intended to highlight a few of the more-important practices to help manage 'Chandler' plant size to create a more-open canopy for easier picking and higher-quality fruit (Fig. 11 top). Possibly, the most critical factor influencing plant size is planting date. In each new region where 'Chandler' plasticulture is attempted, it is important to establish the optimum planting date with field trials. Time of planting trials at the Central
Fig. 10. In coastal-plain North Carolina, floating rowcovers can provide protection for strawberry crowns and flower buds during advective freezes in late winter, but the rowcovers are not used for sprint radiation frosts, when strawberry blossoms are protected more reliably with overhead sprinkler irrigation. 

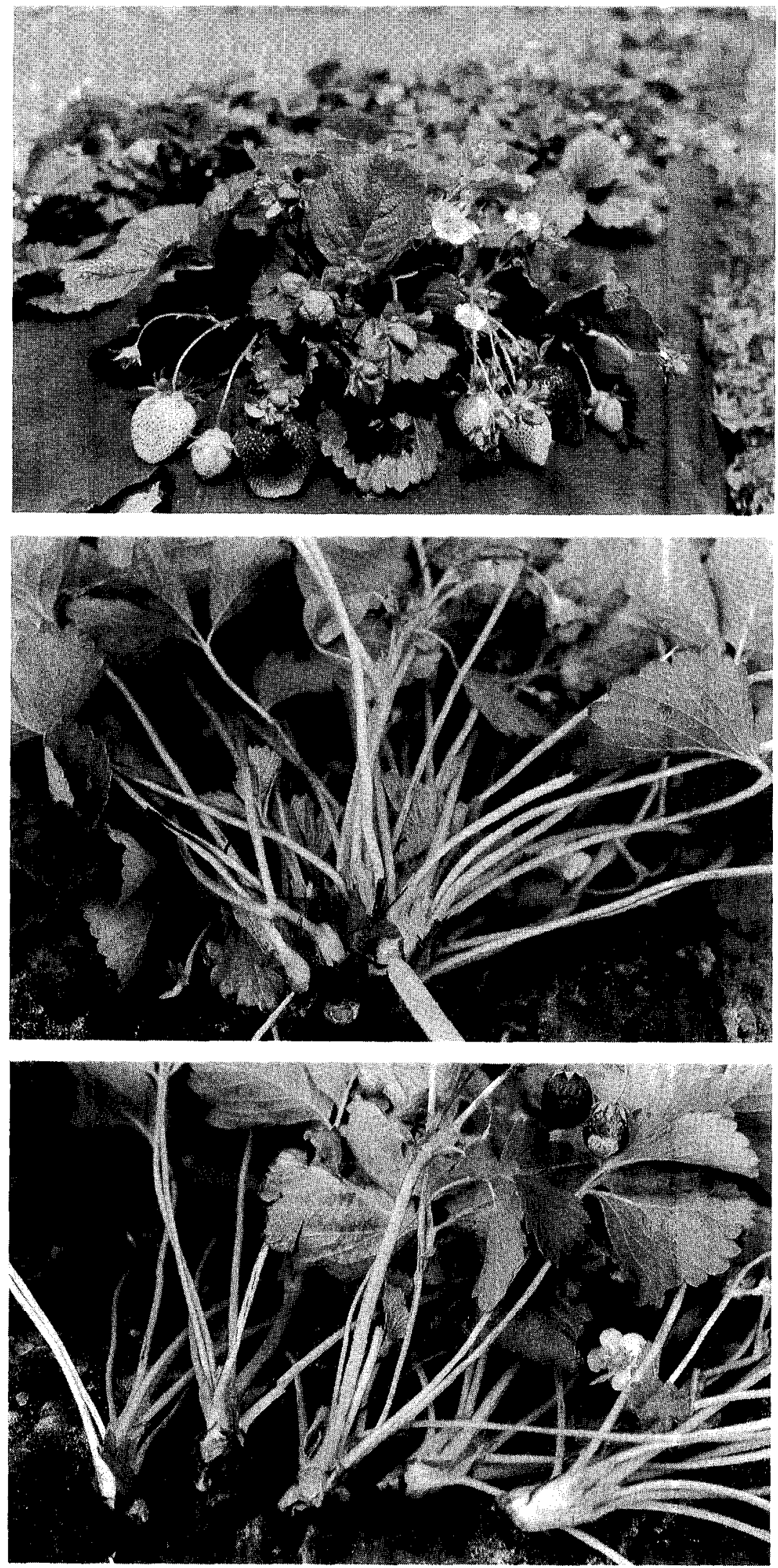

Fig. 11. (Top) In research studies at the Central Crops Research Station, Clayton, N.C., the best planting date for Chandler is in the first week of October. (Middle) Berries on this compact plant are picked easily (canopy not excessive); fruit weight will average $\approx 20$ g; and total marketable yield should exceed $1 \mathrm{lb}(454 \mathrm{~g})$ (photo taken in late April). (Bottom) Following the final harvest in early June, the shoot portion of the plant can be severed to reveal branch formation (five branch crowns is optimum).
Crops Research Station, Clayton, N.C. (lat. $35^{\circ} 40^{\prime} \mathrm{N}$, long. $78^{\circ} 30^{\prime} \mathrm{W}$, elev. $106 \mathrm{~m}$ ) have consistently demonstrated that the optimum planting window is during the first week in October (Fig. 11 middle). Earlier planting dates can result in larger plants with as many as eight to 10 branch crowns. Thick canopies hinder picking and will result in greater disease pressure from reduced air circulation; air movement is also needed to enhance pollination and fruit set. 'Chandler' plant size management also entails decisions regarding plant spacing, irrigation, and fertilizer practices. In North Carolina, the influence of 'Chandler' in-row plant spacing on marketable yield and fruit quality has not been investigated adequately. The $12 \times 12$ inch $(30.5 \times 30.5-\mathrm{cm})$ plant spacing usually is recommended, but a number of growers recently have adopted a wider in-row spacing because of problems with excess 'Chandler' plant vigor. The 14-inch $(35.6-\mathrm{cm})$ in-row spacing allows easier picking, improved spray penetration, and less botrytis fruit rot than closer plant spacing. However, many growers inadvertently are creating a plant "spacing problem" by planting too early, applying excessive amounts of $\mathrm{N}$ and $\mathrm{K}$ preplant fertilizer, and by overwatering with their drip irrigation systems. An interdisciplinary team is currently investigating thevarious relationships between plant spacing and different fertilization practices on the fresh fruit quality, size, and shelflife of 'Chandler' strawberry grown in plasticulture. As a convenient means of assessing 'Chandler' plant size, the grower can simply remove the above-ground portion of the plant at the end of the harvest and count the number of branch crowns. Optimum plant size characteristics and fruit size and quality are associated with the production of five to six branch crowns (Fig. 11 bottom).

\section{Conclusion}

Strawberry plasticulture has replaced bare-ground matted-row culture in much of North Carolina. The major advantages of this system are:

- uniform plant stands every year-unaffected by summer disease, drought, or weed competition;

- earlier picking-about 2 weeks;

- larger berry size;

- easier picking; and

- shorter turnaround time from planting to harvest (7 months).

Against these advantages, one must consider higher initial plant costs, higher costs for hand-transplanting, and the fact that this system does not lend itself to renovation for a 2nd year of fruiting. Also, total yields with 
the plastic mulch system may be no better than yields from matted rows, yet establishment costs can be higher. There is considerably less margin for error with this production system. It is suggested that even seasoned strawberry growers consider only a 0.5 - to 1 acre $(0.2$ to $0.4 \mathrm{ha})$ initial planting to "learn the ropes" of strawberry plasticulture before making a large financial commitment.

\section{Literature Cited}

Ballington, J.R. and R.D. Milholland. 1993. Screen ing strawberries for resistance to Colletotrichum acutatum in North Carolina. Acta Hort. (In press.)

Galletta, G.J. and D.H. Scott. 1970. The 'Apollo' and 'Atlas' strawberries. North Carolina State Univ. Agr. Expt. Sta. Bul. 438.

Hochmuth, G.J. 1992. Concepts and practices for improving nitrogen management for vegetables. HortTechnology 2(1):121-125.

Lamont, W.T. 1989. Use of a portable pumping and filtering' $\&$ for on-farm plastic mulch-drip irrigation demonstrations. HortScience 24(5):848-849.

Lamont, W.J. 1991. Drip irrigation for plasticulture strawberry production. Proc. 21st Annu. Conf., N.C. Strawberry Assn., Inc. 21-22 Nov. 1991. p. $2-6$.

Poling, E.B. 1992. A two-year field comparison of

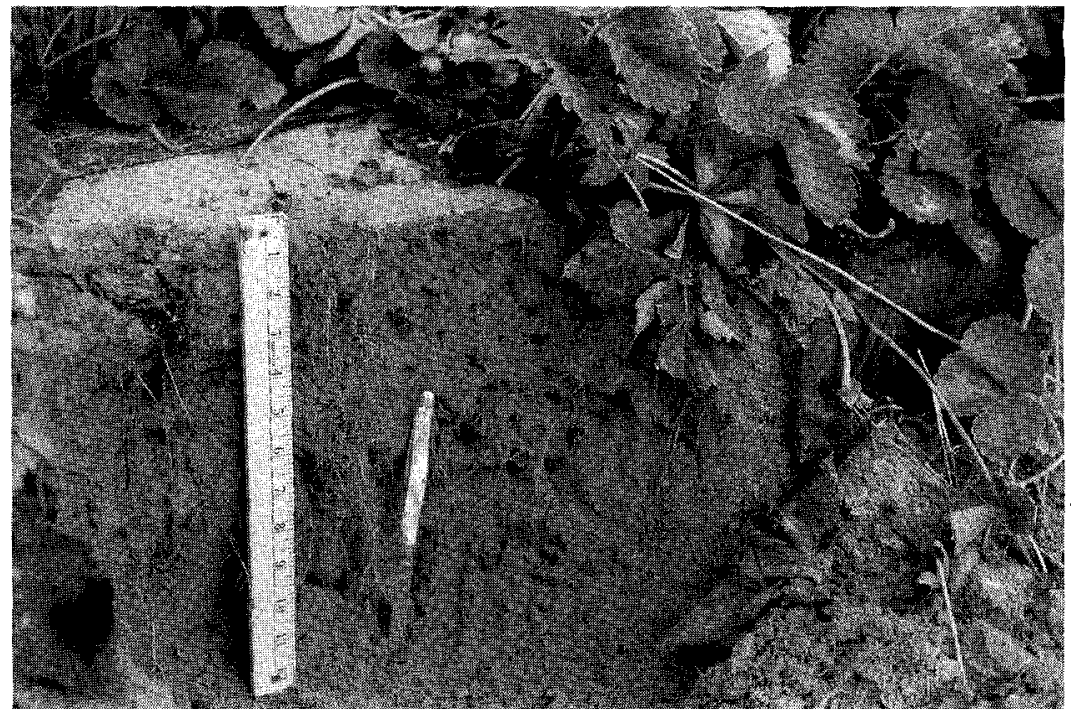

Fig. 12. In a soil with good internal drainage, strawberry roots will penetrate to a depth of 12 to 14 inches (30 to $35 \mathrm{~cm}$ ). tic mulch. 2nd Intl. Strawberry Symp., Baltimore, Md., 13-20 Sept. 1992 (In press.)

Poling, E.B., K.B. Perry, W.J. Lamont, and J.B. Earp. 1988. Annual hill system strawberry research. Hort. Sci. Res. Ser. 76, N.C. Agr. Res. Ser.

Poling, E.B., H.T. Fuller, and K.B. Perry. 1991. Frost/freeze protection of strawberries grown on black plastic mulch. HortScience 26:15-17. 